\title{
Perbandingan Matriks Pembobot Spasial Optimum dalam Spatial Error Model (SEM) (Kasus : Indeks Pembangunan Manusia Kabupaten/Kota di Provinsi Sulawesi Selatan Tahun 2015)
}

\author{
Afif Arif*, Muhammad Arif Tiro, \& Muhammad Nusrang \\ Program Studi Statistika, Fakultas Matematika dan Ilmu Pengetahuan Alam, Universitas Negeri Makassar, Indonesia
}

Keywords: IPM, Analisis Regresi Spasial, SEM.

\begin{abstract}
:
Matriks pembobot spasial merupakan komponen penting dalam kebanyakan model ketika representasi struktur spasial dibutuhkan. Karena hasil analisis sensitif terhadap spesifikasi matriks pembobot (W). Maka matriks bobot spasial yang berbeda mungkin diperlukan untuk berbagai jenis studi. Pada penelitian ini, peneliti melihat matriks pembobot optimum pada model SEM dengan menggunakan beberapa tipe matriks pembobot, di antaranya W Queen tidak terbakukan, W Queen terbakukan, W Rook, dan W Bishop. Dengan cara mngevaluasi nilai Akaike Information Criterion (AIC) terbaik dari dugaan model-model yang dihasilkan dari data Indeks Pembangunan Manusia (IPM) yang selanjutnya diperoleh pendekatan W terbaik dari hasil penelitian. Dari hasil penelitian ini dapat disimpulkan bahwa matriks pembobot tipe W Queen terbakukan merupakan model yang lebih baik dalam menjelaskan peubah respon karena memiliki nilai AIC yang terbaik bila dibandingkan dengan Matriks pembobot lainnya.
\end{abstract}

\section{Pendahuluan}

Indeks Pembangunan Manusia (IPM) dalam arti khusus adalah sebagai suatu indikator ukuran kualitas hidup manusia dibangun melalui 4 komponen dasar yaitu angka harapan hidup yang mewakili bidang kesehatan, angka melek huruf dan angka rata-rata lama sekolah yang mengukur capaian di bidang pendidikan dan kemampuan daya beli masyarakat. Adanya peningkatan IPM dari tahun ke tahun merupakan adanya kelembaman (ingtertia) yang merupakan Salah satu ciri yang menonjol dari sebagian data runtun waktu menunjukkan adanya pola konjungtur. Dalam situasi seperti ini, data observasi pada periode sebelumnya dan periode sekarang kemungkinan besar akan saling ketergantungan (interdependence) sehingga dari faktor-faktor yang mempengaruhi IPM kemungkinan terjadi autokorelasi antar daerah. Sehingga analisis yang memperhatikan pengaruh spasial diharapkan dapat lebih akurat dalam melakukan pendugaan parameter yang dapat mempengaruhi IPM.

Data spasial sendiri merupakan data pengukuran yang memuat suatu informasi lokasi. Pada data spasial, seringkali pengamatan di suatu lokasi bergantung pada pengamatan di suatu lokasi lain yang berdekatan. Cressie (1991) menyatakan bahwa data spasial merupakan salah satu jenis data terikat (dependent) yaitu data pada suatu lokasi dipengaruhi oleh pengukuran data pada suatu lokasi yang lain. Akibatnya, apabila data spasial diselesaikan menggunakan analisis regresi linier akan menghasilkan model yang tidak tepat dan tidak terdapat ketergantungan

\footnotetext{
* Corresponding author.

E-mail address: aditio.putra@gmail.com
} 
antar error (autokorelasi) di tiap lokasi pengamatan. Oleh karena itu dalam pemodelan statistik, apabila model regresi klasik digunakan sebagai alat analisis pada data spasial dapat menyebabkan kesimpulan yang kurang tepat karena asumsi error saling bebas dan asumsi homogenitas tidak terpenuhi. Salah satu ciri khas dalam model regresi spasial yaitu adanya dependensi (ketergantungan) antar lokasi yang menyebabkan pendugaan model bisa menjadi lebih kompleks. Pengaruh dependensi spasial digambarkan dengan adanya kemiripan sifat dari lokasi yang saling memiliki sifat ketetanggaan.

Sebagaimana dijelaskan oleh Getis dan Aldstads (2004) bahwa dalam model spasial, matriks pembobot spasial merupakan komponen penting dalam kebanyakan model ketika representasi struktur spasial dibutuhkan. Karena hasil analisis sensitif terhadap spesifikasi matriks bobot. matriks bobot spasial yang berbeda mungkin diperlukan untuk berbagai jenis studi. Pada penelitian ini, peneliti ingin melihat matriks pembobot optimum pada model yang terbentuk dengan menggunakan beberapa tipe matriks pembobot, diantaranya W Queen tidak terbakukan, W Queen terbakukan, W Rook, dan W Bishop dengan cara mngevaluasi nilai AIC terbaik dari dugaan model-model yang dihasilkan dari data sekunder yang selanjutnya dapat diperoleh pendekatan $\mathrm{W}$ terbaik dari hasil penelitian.

\section{Tinjauan Pustaka}

\subsection{Model Regresi Klasik}

Analisis regresi merupakan alat statistik yang banyak digunakan dalam berbagai bidang. Analisis tersebut bertujuan untuk mengetahui hubungan antara variabel dependen dan variabel independen.

Persamaan regresi berganda adalah persamaan regresi dengan satu peubah dependen $(\boldsymbol{Y})$ dengan lebih dari satu peubah independen $\left(\mathrm{X}_{1}, \mathrm{X}_{2}, \ldots, \mathrm{X}_{\mathrm{p}}\right)$. Hubungan antara peubah-peubah tersebut dapat dirumuskan dalam bentuk model:

$$
Y_{i}=\beta_{0}+\beta_{1} X_{1 i}+\beta_{2} X_{2 i}+\ldots+\beta_{p} X_{p i}+\varepsilon_{i}
$$

Dimana $\beta 0$ merupakan konstanta dan $\beta p$ merupakan koefisien regresi peubah independen ke $p$. Bila dituliskan dalam bentuk matriks:

$$
\boldsymbol{Y}=\boldsymbol{X}_{\boldsymbol{\beta}}+\boldsymbol{\varepsilon}
$$

Asumsi-asumsi yang mendasari model regresi adalah:

a) $\varepsilon i$ memiliki ragam homogen atau disebut juga tidak ada masalah heteroskedastisitas.

b) $\varepsilon i$ dan $\varepsilon j$ tidak berkorelasi, $i \neq j$, sehingga $\operatorname{cov}(\varepsilon i, \varepsilon j)=0$.

c) $\varepsilon i$ merupakan peubah acak normal dengan nilai tengah nol dan ragam $\sigma 2$. Dengan kata lain, $\varepsilon i \sim N(0, \sigma 2)$.

Nilai dugaan bagi $\beta$ diperoleh dengan menggunakan metode jumlah kuadrat terkecil, yaitu dengan meminimumkan $\sum_{i=1}^{n} \varepsilon_{i}{ }^{2}$. sehingga nilai dugaan $\beta$ bagi yaitu:

$$
\widehat{\beta}=\left(\boldsymbol{X}^{T} \boldsymbol{X}\right)^{-1} \boldsymbol{X}^{T} Y
$$

\subsection{Matriks Pembobot}

Matriks pembobot spasial merupakan komponen penting dalam pemodelan datadata spasial dimana pada data tersebut terdapat ketakbebasan spasial (spatial dependence).

Matriks pembobot spasial $\boldsymbol{W}$, merupakan matriks $n \times n$ tak negatif yang menspesifikasi himpunan ketetanggaan untuk setiap unit amatan spasial.

\subsubsection{Queen Contiguity}

Queen contiguity ialah persentuhan sisi maupun titik sudut wilayah satu dengan wilayah yang lain yaitu gabungan rook contiguity dan bishop contiguity. 


\subsubsection{Rook Contiguity}

Rook contiguity ialah persentuhan sisi wilayah satu dengan sisi wilayah yang lain yang bertetangga.

\subsubsection{Bishop Contiguity}

Bishop contiguity ialah persentuhan titik sudut wilayah satu dengan wilayah lain yang bertetangga.

\subsection{Uji Autokorelasi Spasial}

Autokorelasi spasial adalah taksiran dari korelasi antar nilai amatan yang berkaitan dengan lokasi spasial pada variabel yang sama. Autokorelasi spasial positif menunjukkan adanya kemiripan nilai dari lokasi-lokasi yang berdekatan dan cenderung berkelompok. Sedangkan autokorelasi spasial yang negatif menunjukkan bahwa lokasilokasi yang berdekatan mempunyai nilai yang berbeda dan cenderung menyebar.

Menurut Kosfeld perhitungan autokorelasi spasial dengan metode Indeks Moran dapat dilakukan dengan dua cara yaitu Indeks Moran dengan matriks pembobot spasial tidak terstandarisasi dan Indeks Moran dengan matriks pembobot spasial terstandarisasi. Salah satunya adalah :

Indeks Moran dengan matriks pembobot spasial tidak terstandarisasi W :

$$
I=\frac{n \sum_{i=1}^{n} \sum_{j=1}^{n} w_{i j}{ }^{*}\left(x_{j}-\bar{x}\right)\left(x_{j}-\bar{x}\right)}{S_{0} \sum_{i=1}^{n}\left(x_{i}-\bar{x}\right)}
$$

Indeks Moran dengan matriks pembobot spasial terstandarisasi $W$ :

$$
I=\frac{n \sum_{i=1}^{n} \sum_{j=1}^{n} w_{i j}\left(x_{j}-\bar{x}\right)\left(x_{j}-\bar{x}\right)}{\sum_{i=1}^{n}\left(x_{i}-\bar{x}\right)^{2}}
$$

dengan $I$ adalah Indeks Moran, $n$ adalah banyaknya lokasi kejadian, $x_{i}$ adalah nilai pada lokasi $i, x_{j}$ adalah nilai pada lokasi $j, \bar{x}$ adalah rata-ratadari jumlah variabel atau nilai,$w_{i j} *$ adalah elemen pada pembobot tak terstandarisasi antara daerah $i$ dan $j, w_{i j}$ adalah elemen pada pembobot terstandarisasi antara daerah $i$ dan $j$ dan $S_{0}$ adalah jumlah dari elemen matriks pembobot.

Uji hipotesis untuk Indeks Moran adalah sebagai berikut:

a) Hipotesis

$H 0: I=0$ (tidak ada autokorelasi antar lokasi)

$H 1: I \neq 0$ (ada autokorelasi antar lokasi)

b) Tingkat signigikansi $=\alpha$

c) Statistik uji:

dengan:

$$
Z(I)=\frac{I-E(I)}{\sqrt{\operatorname{Var}(I)}} \approx N(0,1)
$$

$$
E(I)=-\frac{1}{n-1} \operatorname{dan} \operatorname{Var}(I)=\frac{n^{2} \cdot S_{1}-n \cdot S_{2}+3, S_{0}{ }^{2}}{\left(n^{2}-1\right) S_{0}{ }^{2}}-\lfloor E(I)\rfloor^{2}
$$

Tolak $H_{0}$ pada taraf signifikasi $\alpha$ jika $Z(I)>Z_{1-\alpha}$ dengan $Z_{1-\alpha}$ adalah $(1-\alpha)$ kuantil dari distribusi normal standar. 


\subsection{Uji Heteroskedastisitas Spasial}

Efek heterogenitas adalah efek yang menunjukkan adanya keragaman antar lokasi. Jadi setiap lokasi mempunyai struktur dan parameter hubungan yang berbeda. Pengujian efek spasial dilakukan dengan uji heterogenitas yaitu menggunakan uji Breusch-Pagan test (BP test). Uji BP dapat digunakan untuk mendeteksi asumsi kehomogenan ragam sisaan.

Hipotesis yang diuji adalah sebagai:

$H 0=$ Terdapat Homogenitas Spasial

$H 1=$ Terdapat Heterogenitas Spasial

Statistik uji BP adalah sebagai berikut :

$$
B P=\frac{1}{2} \boldsymbol{f}^{T} \boldsymbol{Z}\left(\boldsymbol{Z}^{T} \boldsymbol{Z}\right)^{-1} \boldsymbol{Z}^{T} \boldsymbol{f}+\left(\frac{1}{T}\right)\left[\frac{\boldsymbol{e}^{T} \boldsymbol{W} \boldsymbol{e}}{\boldsymbol{\sigma}^{2}}\right]^{2} \sim \chi_{(p+1)}^{2}
$$

Pengambilan keputusan $H_{0}$ ditolak jika BP $>\chi_{p}^{2}$ atau $p$-value kurang dari $\alpha$.

\subsection{Uji ketergantungan Spasial}

Uji Lagrange Multiplier (LM test) digunakan sebagai dasar untuk memilih model regresi spasial yang sesuai (LeSage,2009). Uji yang digunakan untuk mengetahui model pengaruh spasial dalam data adalah menggunakan uji Lagrange Multiplier. Pengujian hipotesis Pengganda Lagrange adalah:

1. Model Regresi Spatial Autoregressive (SAR)

Hipotesis untuk model SAR adalah sebagai berikut:

H0 : $\rho=0$ (tidak ada ketergantungan spasial lag)

$\mathrm{H} 1: \rho \neq 0$ (ada ketergantungan spasial lag)

2. Model Spatial Error Model (SEM)

Hipotesis untuk model SEM adalah sebagai berikut:

H0: $\lambda=0$ (tidak ada ketergantungan kesalahan spasial)

$\mathrm{H} 1: \lambda \neq 0$ (ada ketergantungan kesalahan spasial)

Statistik LM yang digunakan untuk Model Spatial Autoregressive (SAR) adalah sebagai berikut:

$$
L M_{L A G}=\frac{\left(\boldsymbol{e}^{T} \boldsymbol{W} \boldsymbol{y} / \hat{\sigma}^{2}\right)^{2}}{D} \sim \chi_{(\alpha, 1)}
$$

Statistik LM yang digunakan untuk Regresi Spasial Error Model (SEM) adalah sebagai berikut:

$$
L M_{E R R}=\frac{\left(\boldsymbol{e}^{\prime} \boldsymbol{W} e / \hat{\sigma}^{2}\right)^{2}}{T} \sim \chi_{(\alpha, 1)}
$$

Keputusan tolak $H_{0}$ dilakukan jika nilai statistik $L M$ lebih besar dari $\chi_{(p)}^{2}$, dengan $q$ adalah banyaknya parameter spasial yaitu 1, atau nilai-p lebih kecil dari taraf nyata $\alpha$ (Anselin 2009).

\subsection{Model Regresi Spasial}

\subsubsection{Spatial Autoregressive (SAR)}

Model Spatial Autoregressive (SAR) atau Spatial Lag Model (SLM) adalah model yang mengkombinasikan model regresi linear dengan lag spasial pada variabel respon dengan menggunakan data cross section (Anselin, 1988). 
Spasial lag muncul saat nilai observasi variabel respon pada suatu lokasi berkorelasi dengan nilai observasi variabel respon di lokasi sekitarnya atau dengan kata lain terdapat korelasi spasial antar variabel respon. Pada model ini terdapat fungsi dari variabel respon pada lokasi $j$ yang digunakan sebagai variable prediktor untuk memprediksi nilai dari variabel respon pada lokasi $i$.

Model SAR merupakan model regresi linier yang pada peubah responnya terdapat korelasi spasial (Anselin 1999). Model umum untuk SAR adalah sebagai berikut:

$$
\begin{aligned}
& \boldsymbol{Y}=\rho \boldsymbol{W} \boldsymbol{y}+\boldsymbol{X} \boldsymbol{\beta}+\boldsymbol{\varepsilon} \\
& \boldsymbol{\varepsilon} \sim N\left(0, \sigma^{2} \boldsymbol{I}\right)
\end{aligned}
$$

Parameter lag spasial $(\rho)$ menunjukkan tingkat korelasi pengaruh spasial dari suatu wilayah terhadap wilayah lain di sekitarnya (Ward \& Kristiani 2008).

Pendugaan $\mathrm{n}$ untuk sisaan $(\varepsilon)$ adalah sebagai berikut :

$$
\begin{aligned}
\boldsymbol{Y} & =\rho \boldsymbol{W} \boldsymbol{Y}+\boldsymbol{X} \boldsymbol{\beta}+\boldsymbol{\varepsilon} \\
(\boldsymbol{I}-\boldsymbol{\rho} \boldsymbol{W}) \boldsymbol{Y} & =\boldsymbol{X} \boldsymbol{\beta}+\boldsymbol{\varepsilon} \\
\boldsymbol{\varepsilon} & =(\boldsymbol{I}-\boldsymbol{\rho} \boldsymbol{W}) \boldsymbol{Y}-\boldsymbol{X} \boldsymbol{\beta}
\end{aligned}
$$

Dengan $\rho$ adalah koefisien otoregresif lag spasial dan $\boldsymbol{W}$ adalah matriks pembobot spasial dengan ukuran $(n \times n), \boldsymbol{y}$ merupakan vektor peubah respon berukuran $(n \times 1), \boldsymbol{X}$ merupakan matriks peubah penjelas berukuran $(n \times k), \boldsymbol{\beta}$ merupakan vektor parameter yang akan diduga dengan ukuran $\left(\begin{array}{lll}k & x & 1\end{array}\right)$, dan $\boldsymbol{\varepsilon}$ adalah vektor galat model berukuran $\left(\begin{array}{lll}n & x & 1\end{array}\right)$. Pendugaan parameter untuk $\boldsymbol{\beta}$ diperoleh dengan cara Ordinary Least Square (OLS). Sehingga penduga $\boldsymbol{\beta}$ untuk Model SAR adalah sebagai berikut:

$$
\widehat{\boldsymbol{\beta}}=\left(X^{T} X\right)^{-1} X^{T}([I-\rho W] Y)
$$

Penduga untuk $\rho$ diperoleh dengan menggunakan OLS, sehingga penduga untuk $\rho$ adalah:

$$
\widehat{\rho}=\left(\boldsymbol{Y}^{T} \boldsymbol{W}^{T} \boldsymbol{W} \boldsymbol{Y}\right)^{-1} \boldsymbol{Y}^{T} \boldsymbol{W}^{T} \boldsymbol{Y}
$$

dan penduga untuk $\sigma 2$ adalah:

$$
\widehat{\sigma^{2}}=\frac{(\boldsymbol{Y}-\rho \boldsymbol{W} \boldsymbol{Y}-\boldsymbol{X} \boldsymbol{\beta})^{T}(\boldsymbol{Y}-\rho \boldsymbol{W} \boldsymbol{Y}-\boldsymbol{X} \boldsymbol{\beta})}{n}
$$

(Anselin,1988).

\subsubsection{Spatial Error Model (SEM)}

Spatial Error Model (SEM) adalah model regresi spasial dimana ketergantungan spasial masuk melalui eror, bukan melalui komponen sistematis dari model. Artinya, eror masih dapat menjelaskan komponen sistematis spasial. Spatial Error Model muncul saat nilai eror pada suatu lokasi berkorelasi dengan nilai error di lokasi sekitarnya atau dengan kata lain terdapat korelasi spasial antar error.

Model Spasial Eror ditunjukkan dalam bentuk sebagai berikut:

$$
\begin{aligned}
& \mathbf{Y}=\boldsymbol{X} \boldsymbol{\beta}+\mathbf{u} \\
& \boldsymbol{u}=\lambda \boldsymbol{W} \mathbf{u}+\boldsymbol{\varepsilon} \\
& \boldsymbol{\varepsilon} \sim N\left(0, \sigma^{2} \boldsymbol{I}_{n}\right)
\end{aligned}
$$

Dimana $\mathbf{Y}$ adalah peubah bebas, $\boldsymbol{X}$ adalah matriks peubah tak bebas, $\boldsymbol{W}$ adalah matriks pembobot spasial, $\boldsymbol{\lambda}$ adalah koefisien prediktor Model Spasial Eror, $\boldsymbol{\varepsilon}$ adalah eror yang tidak berkorelasi spasial memenuhi asumi regresi klasik, 
dan $\boldsymbol{u}$ adalah vektor eror yang diasumsikan mengandung autokorelasi.

Fungsi peluang bersama dari variabel respon $Y$ diperoleh dengan mentransformasi persamaan berikut:

$$
\begin{aligned}
\boldsymbol{u} & =\lambda \boldsymbol{W} \boldsymbol{u}+\boldsymbol{\varepsilon} \\
(\boldsymbol{I}-\lambda \boldsymbol{W}) \boldsymbol{u} & =\boldsymbol{\varepsilon} \\
\boldsymbol{u} & =(\boldsymbol{I}-\lambda \boldsymbol{W})^{-\mathbf{1}} \boldsymbol{\varepsilon} \\
Y & =\boldsymbol{X} \boldsymbol{\beta}+(\boldsymbol{I}-\lambda \boldsymbol{W})^{-\mathbf{1}} \boldsymbol{\varepsilon} \\
(\boldsymbol{I}-\lambda \boldsymbol{W}) \boldsymbol{Y} & =(\boldsymbol{I}-\lambda \boldsymbol{W}) \boldsymbol{X} \boldsymbol{\beta}+\boldsymbol{\varepsilon} \\
\boldsymbol{\varepsilon} & =(\boldsymbol{I}-\lambda \boldsymbol{W})(\boldsymbol{Y}-\boldsymbol{X} \boldsymbol{\beta})
\end{aligned}
$$

parameter $\boldsymbol{\beta}$ adalah estimator untuk $\boldsymbol{\beta}$ adalah sebagai berikut:

$$
\widehat{\boldsymbol{\beta}}=\left[(X-\lambda W X)^{T}(X-\lambda W X)\right]^{-1}\left((X-\lambda W X)^{T}(Y-\lambda W Y)\right)
$$

Penduga untuk $\sigma^{2}$ adalah:

$$
\widehat{\sigma^{2}}=\frac{\left[(\boldsymbol{I}-\lambda \boldsymbol{W})(\boldsymbol{Y}-\boldsymbol{X} \boldsymbol{\beta})^{\prime}(\boldsymbol{I}-\lambda \boldsymbol{W})(\boldsymbol{Y}-\boldsymbol{X} \boldsymbol{\beta})\right]}{n}
$$

Untuk menduga parameter $\lambda$ diperlukan suatu iterasi numerik untuk mendapatkan penduga untuk $\lambda$ yang memaksimalkan fungsi log likelihood Spasial Error Model (Anselin,1988).

\subsubsection{Spatial Autoregressive Moving Average (SARMA)}

Regresi Spatial Autoregressive Moving Average (SARMA) adalah model regresi spasial yang menggunakan pendekatan spasial area. Matriks yang digunakan adalah matriks ketetanggaan yang didasarkan pada persinggungan antar lokasi yang diamati. Jika pada data yang dianalisis terdapat dependensi pada lag variabel respon dan dependensi pada eror maka pemodelan yang sesuai adalah SARMA.

Bentuk umum persamaan SARMA (Lesage, 2009) adalah sebagai berikut:

$$
\begin{aligned}
& \boldsymbol{Y}=\rho \boldsymbol{W} \boldsymbol{Y}+\boldsymbol{X} \boldsymbol{\beta}+(\boldsymbol{I}-\boldsymbol{\lambda} \boldsymbol{W})^{-1} \boldsymbol{\varepsilon} \\
& \boldsymbol{\varepsilon} \sim N\left(0, \sigma^{2} \boldsymbol{I}\right)
\end{aligned}
$$

Adapun bentuk penaskir parameter dari model regresi SARMA, yaitu sebagai berikut:

$$
\widehat{\boldsymbol{\beta}}=\left[(X-\lambda W X)^{T}(X-\lambda W X)\right]^{-1}(X-\lambda W X)^{T}(I-\lambda W-\rho W) Y
$$

\subsubsection{Pengujian Signifikansi Parameter}

Pengujian terhadap parameter model dilakukan untuk mengetahui peranan variable independen dalam model. Pengujian hipotesis untuk signifikansi parameter pada penelitian ini menggunakan uji Wald. Rumus untuk uji Wald berdasarkan hipotesis adalah sebagai berikut (Anselin, 1988).

$H 0=\hat{\rho}=0, \beta j=0$ (Parameter signifikan)

$H 1=\hat{\rho, \beta j} \neq 0$ (Parameter tidak signifikan)

statistik uji yang digunakan adalah pada persamaan(Anselin, 1988): 


$$
W=\left[\frac{\hat{\beta}_{j}{ }^{2}}{\operatorname{var}\left(\hat{\beta}_{j}\right)}\right]
$$

dengan $\hat{\rho}$ menyatakan penduga parameter $\rho, \beta j$ menyatakan penduga parameter ke- $j, \operatorname{var}(\beta j)$ dan menyatakan varians parameter ke-j. Kriteria pengambilan keputusan adalah mengikuti sebaran $\chi \alpha 2,1$.H0 ditolak jika nilai $W>$ $\chi \alpha 2,1$.

\subsubsection{Kriteria Pemilihan Model Terbaik}

Kriteria pemilihan model dilakukan dengan menggunakan Akaike Information Criterion (AIC ). Jika nilai AIC lebih kecil, maka model tersebut dikatakan lebih baik.

Rumus $A I C$ dapat ditunjukkan sebagai berikut:

$$
A I C=-2 l+2 p
$$

Dimana $l$ adalah $\log$ likelihood dan $p$ adalah banyaknya parameter (Ismail \& Jemain 2007).

\subsubsection{Indeks Pembangunan Manusia}

Manusia adalah kekayaan bangsa yang sesungguhnya sehingga tujuan akhir pembangunan harus difokuskan pada manusia. Kondisi ini akan menciptakan lingkungan yang memungkinkan masyarakat untuk dapat menikmati umur panjang, sehat, dan menjalankan kehidupan yang produktif. Konsep ini menjadi cikal bakal munculnya Indeks Pembangunan Manusia (IPM). United Nations Development Programme (UNDP) memperkenalkan IPM pertama kali pada tahun 1990. Saat itu, IPM dibentuk dari empat indikator yang merefleksikan dimensi umur panjang dan hidup sehat, pengetahuan, dan standar hidup layak. Keempat indikator tersebut adalah angka harapan hidup saat lahir, angka melek huruf, gabungan angka partisipasi kasar, dan Produk Domestik Bruto (PDB) per kapita. Sejak saat itu, IPM secara berkala dipublikasikan setiap tahun dalam suatu Laporan Pembangunan Manusia (Human Development Report).

\section{Metode Penelitian}

\subsection{Data Penelitian}

Sumber data yang digunakan dalam penelitian ini adalah data sekunder yang dipublikasikan oleh badan pusat statistik (BPS). Adapun peubah respon yang digunakan adalah IPM Kabupaten/Kota di Provinsi Sulawesi Selatan Tahun 2015. Sedangkan peubah penjelas yang diduga mempengaruhi pertumbuhan IPM yaitu rasio sekolah murid (RSM), kepadatan penduduk, dan fasilitas kesehatan. Obyek dari penelitian ini adalah 24 IPM Kabupaten/Kota di Provinsi Sulawesi Selatan, yang terdiri dari 3 Kota dan 21 Kabupaten.

Tabel 1 Peubah-peubah penelitian

\begin{tabular}{ccl}
\hline Peubah & Keterangan & Skala \\
\hline $\mathrm{Y}$ & Indeks pembangunan manusia & Rasio \\
$\mathrm{X}_{1}$ & Rasio sekolah murid & Rasio \\
$\mathrm{X}_{2}$ & Kepadatan penduduk & Rasio \\
$\mathrm{X}_{3}$ & Fasilitas kesehatan & Rasio \\
\hline
\end{tabular}




\subsection{Metode Analisis}

Metode penelitian yang akan digunakan sebagai langkah-langkah pada penelitian ini akan dijelaskan sebagai berikut:

(1) Melakukan eksplorasi data.

(2) Menentukan peubah-peubah penjelas yang digunakan dalam pendugaan model

(3) Melakukan analisis regresi klasik dan pemeriksaan asumsi untuk mengetahui apakah data memenuhi asumsi untuk dilakukan analisis regresi spasial.

(4) Menentukan pembobot spasial (W) yaitu Queen contiguity tidak terbakukan, Queen contiguity terbakukan, Rook contiguity dan Bishop contiguity. Langkah-langkan menentukan matriks pembobot:

a) Mendeskripsikan data dalam bentuk peta secara statistik.

b) Menentukan elemen dalam matriks pembobot dengan melihat persentuhan sisi maupun titik sudut wilayah satu dengan wilayah yang lain.

(5) Uji ketergantungan spasial atau korelasi antara pengamatan yang saling berdekatan dengan indeks moran atau Moran'suntuk masingI-masing nilai W pada eror regresi klasik.

(6) Uji efek spasial dilakukan dengan uji heterogenitas yaitu menggunakan uji Breusch-Pagan test (BP test) untuk masing-masing nilai $\mathrm{W}$.

(7) Melakukan uji Lagrange multiplier dalam pendugaan Model SEM untuk masing-masing matriks pembobot yang digunakan.

(8) Melakukan analisis regresi spasial untuk model yang nyata pada Uji Lagrange.

(9) Melakukan pendugaan dan pengujian parameter untuk masing-masing matriks pembobot yang digunakan.

(10) Memilih matriks pembobot optimum dengan melihat nilai AIC masing-masing output dari matriks pembobot yang digunakan.

(11) Interpretasi hasil analisis Spatial Error Model (SEM).

\section{Hasil dan Pembahasan}

\subsection{Model regresi klasik}

Model regresi klasik dapat digunakan untuk melihat hubungan antara IPM setiap kabupaten/kota di Provinsi Sulawesi Selatan dengan faktor-faktor yang berpengaruh terhadap IPM. Kemudian dilakukan pengujian secara serentak dan parsial untuk mengetahui peubah-peubah yang signifikan. Peubah terikat yang digunakan adalah IPM $(\boldsymbol{Y})$. Nilai duga parameter dapat dilihat pada table 1.

Tabel 2 Pengujian secara parsial

\begin{tabular}{ccccc}
\hline & Estimate & Std. Error & $\mathrm{t}$ value & $\operatorname{Pr}(>|\mathrm{t}|)$ \\
\hline (Intercept) & 67,713 & 3,680 & 18,396 & $<0,001$ \\
1 & 0,113 & 0,245 & 0,460 & 0,650 \\
2 & 0,001 & 0,000 & 4,071 & $<0,001$ \\
3 & $-0,012$ & 0,006 & $-1,778$ & 0,090 \\
\hline
\end{tabular}

Hasil dari output pada Tabel 2 menjelaskan bahwa nilai statistik uji untuk semua parameter pada taraf nyata ()sebesar $5 \%$. Maka peubah prediktor yang berpengaruh nyata terhadap IPM di Provinsi Sulawesi Selatan adalah persentase kepadatan penduduk (X2) dilihat dari nilai $\operatorname{Pr}(>|t|)<0.05$.

Model yang terbentuk adalah sebagai berikut :

$$
Y=67,713+0,113 X_{1}+0,001 X_{2}-0,012 X_{3}
$$

Tabel 3 Pengujian secara simultan

\begin{tabular}{llll}
\hline & $\mathrm{db}$ & F-statistic & $\mathrm{p}$-value \\
\hline Model & 20 & 6,889 & 0,002 \\
\hline
\end{tabular}

Berdasarkan hasil output pada Tebel 3 dapat dilihat bahwa peubah penjelas secara bersama-sama dapat 
mempengaruhi Indeks Pembanguna Manusia dilihat dari nilai Fhitung $(4,071)>t_{\text {tabel }}(3,10)$ atau $p$-value lebih kecil dari $(\alpha)$ sebesar $5 \%$ atau $=0.05$.

\subsection{Analisis Regresi Spasial}

\subsubsection{Uji autokorelasi}

Pengujian indeks moran dilakukan untuk mendeteksi adanya pengaruh spasial (Autokorelasi Spasial) sehingga dapat dilakukan pemodelan spasial autokorelasi. Hasil uji indeks moran dapat dilihat pada Tabel 4.

Tabel 4 Hasil Uji Indeks Moran

\begin{tabular}{ccc}
\hline Matriks pembobot & Moran I statistic & p-value \\
\hline W Queen tidak terbakukan & 2,856 & 0,002 \\
W Queen terbakukan & 2,999 & 0,001 \\
W Rook & 1,896 & 0,028 \\
W Bishop & 1,404 & 0,080 \\
\hline
\end{tabular}

Dari Tabel 4 menunjukkan bahwa nilai Moran I untuk setiap matriks pembobot tipe $\boldsymbol{W}$ Queen tidak terbakukan, $\boldsymbol{W}$ Queen terbakukan dan $\boldsymbol{W}$ Rook, yaitu masing-masing nilai $(2,856),(2,999)$ dan $(1,896)$ adalah lebih besar dari $\mathrm{Z}_{(1-\alpha)}$ $=1,71$ atau p-value dari ketiga jenis pembobot $\boldsymbol{W}<(\alpha=0,05)$, sehingga Tolak $\mathrm{H}_{0}$ yang berarti ada autokorelasi antar lokasi. Sedangkan untuk $\boldsymbol{W}$ Bishop, nilai $\mathrm{Z}(\mathrm{I})=1,404<\mathrm{Z}_{(1-\alpha)}=1,71$ yang berarti terima $\mathrm{H}_{0}$ yaitu tidak terdapat autokorelasi, sehingga $\boldsymbol{W}$ Bishop tidak di gunakan dalam analisis selanjutnya.

\subsubsection{Uji Heteroskedastisitas Spasial}

Uji kehomogenan ragam digunakan untuk mendeteksi asumsi keragaman antar lokasi menggunakan Uji breuschpagan.

Hasil uji keragaman spasial pada uji breusch-pagan disajikan pada tabel 5.

Tabel 5 Hasil uji breusch-pagan

\begin{tabular}{ccc}
\hline Matriks pembobot & BP & p-value \\
\hline W Queen tidak terbakukan & 4,083 & 0,252 \\
W Queen terbakukan & 4,050 & 0,256 \\
W Rook & 4,206 & 0,240 \\
\hline
\end{tabular}

Pada Tabel 4.4 menunjukkan bahwa nilai uji Breusch-pagan masing-masing Matriks pembobot yang digunakan yaitu lebih kecil dari nilai $\chi_{p}^{2}=7,81$ dan $p$-value $>0,05$ yang berarti terima $H 0$ sehingga kesimpulannya terdapat Homogenitas Spasial.

\subsubsection{Uji Lagrange Multiplier}

Uji Lagrange Multiplier (LM test) digunakan sebagai dasar untuk memilih model regresi spasial yang sesuai. Hasil output dapat dilihat pada Tabel 6.

Tabel 6 Hasil Uji Lagrange Multiplier

\begin{tabular}{cllll}
\hline Matriks pembobot & LMlag & p-value & LMerr & p-value \\
\hline W Queen tidak terbakukan & 0,024 & 0,875 & 5,454 & 0,019 \\
W Queen terbakukan & 1,965 & 0,160 & 6,485 & 0,010 \\
W Rook & 2,507 & 0,113 & 3,681 & 0,049 \\
\hline
\end{tabular}


Pada Tabel 6 untuk LMlag menunjukkan nilai p-value untuk masing-masing matriks pembobot yang digunakan lehih besar dari $\alpha=0.05$ sehingga keputusannya menerima $H_{0}$ yaitu tidak ada ketergantungan spasial Lag. Sedangkan nilai LMerr untuk $\boldsymbol{W}$ Queen tidak terbakukan, $\boldsymbol{W}$ Queen terbakukan, dan $\boldsymbol{W}$ Rook lebih kecil dari $\alpha=0,05$, sehingga tolak $H_{0}$ sehingga ada ketergantungan spasial eror (SEM). Jadi model regresi spasial yang sesuai adalah Spasial Eror Model (SEM).

\subsubsection{Pemilihan model terbaik}

Kriteria yang digunakan untuk memilih model adalah nilai AIC. Nilai AIC dapat dilihat pada Tabel 7.

Tabel 7 Nilai AIC untuk masing-masing matriks pembobot

\begin{tabular}{ll}
\hline Matriks pembobot & Nilai AIC \\
\hline W Queen tidak terbakukan & 127,68 \\
W Queen terbakukan & 124,94 \\
W Rook & 127,20 \\
\hline
\end{tabular}

Model dikatakan baik jika memiliki nilai AIC yang lebih kecil. Nilai AIC yang kecil akan memperoleh nilai log kemungkinan yang lebih besar. Tabel 7 menunjukkan bahwa nilai AIC yang lebih kecil terdapat pada Matriks $\boldsymbol{W}$ Queen terstandarisasi, Sehingga matriks pembobot optimum yang dipilih pada model SEM adalah $\boldsymbol{W}$ Queen dengan terstandarisasi dilihat dari nilai AIC terkecil yaitu 124,94.

\section{Kesimpulan}

1. Dari hasil pembahasan menunjukkan bahwa nilai AIC terbaik dalam Spatial Error Model (SEM) terdapat pada matriks pembobot tipe $\boldsymbol{W}$ Queen terbakukan, sehingga matriks pembobot optimum yang dipilih pada model SEM adalah $\boldsymbol{W}$ Queen terbakukan dilihat dari nilai AIC terkecil yaitu 124,94.

2. Model yang terbentuk pada kasus Indeks Pembangunan Manusia di Provinsi Sulawesi Selatan dalam Spatial Error Model (SEM) adalah

$$
\begin{gathered}
\mathrm{y}_{\mathrm{i}}=67,1700+0,144 \mathrm{X}_{1 \mathrm{i}}+0,0018 \mathrm{X}_{2 \mathrm{i}}-0,011 \mathrm{X}_{3 \mathrm{i}}+u_{i} \\
u_{i}=0,626 \sum_{j=1, i \neq j}^{n} W_{i j} u_{j}+\varepsilon_{j}
\end{gathered}
$$

3. Peubah yang berpengaruh signifikan dalam Indeks Pembangunan Manusia (IPM) adalah persentase Kepadatan penduduk $\left(X_{2}\right)$ dan persentase Fasilitas kesehatan $\left(X_{3}\right)$.

\section{References}

Andra, N. (2007). Model Regresi Linear pada Data Spasial Dependen. Skripsi.Fakultas Matematika dan Ilmu Pengetahuan Alam Universitas Indonesia.

Anselin, L. (1988). Spatial Econometrics : Methods and Models. Dordrecht: Kluwer Academic Publishers.

Anselin, L. (1999), Spatial Econometrics, University of Texas, Dallas.

Anselin L. (2009). Spatial Regression. Fotheringham AS, PA Rogerson, editor, Handbook of Spatial Analysis. London: Sage Publications.

Asfar. (2016) Studi Penentuan Matriks Pembobot Optimum dalam Pendugaan Area Kecil. Bogor: Program Pascasarjana Institut Pertanian Bogor.

[BPS] Badan Pusat Statistik. (2015). Indeks Pembangunan Manusia 2015. Jakarta (ID): BPS. Breusch, T. S. and Pagan, A. R. (1979). A simple Test for Heteroscedasticity and Random 
Coefficient Variation. Econometrica vol.47 no. 5, 1287-1294. Cressie N, (1991). Statistic for Spatial data. Chichester, John Wiley \& Sons.

Fatkhurokhman, F. (2016). Model Regresi Spasial Terbaik Indeks Pembangunan Manusia Provinsi Jawa Tengah. Semarang: Jurusan Matematika Fakultas Matematika dan Ilmu Pengetahuan Alam, Universitas Negeri Semarang

Lailatul. S \&, M.S.Endang.L. (2014). Spatial Autoregressive Model and Spatial Weigt Matrix of Rook Contiguity to Modelling. Yogyakarta:Program Studi Matematika, Jurusan Pendidikan Matematika FMIPA UNY.

LeSage. (1999). The Theory and Practice of Spatial Econometrics. Toledo:Department of Economics University of Toledo.

Purwaningsing, T. (2014). Kajian Pengaruh Matriks Pembobot Spasial dalam Model Data Panel Spasial. Bogor: Program Pascasarjana Institut Pertanian Bogor.

Tobler, W.(1961). Map Transformations of Geographic Space. University of Washington. Ph.D Dessertation. 